\title{
REAMED OR UNREAMED NAILING FOR CLOSED TIBIAL FRACTURES
}

\section{A PROSPECTIVE STUDY IN TSCHERNE C1 FRACTURES}

\author{
C. M. COURT-BROWN， E. WILL， J. CHRISTIE， M. M. McQUEEN \\ From the Royal Infirmary of Edinburgh, Scotland
}

$\mathbf{W}$ e performed a prospective, randomised study on 50 patients with Tscherne $\mathrm{C1}$ tibial diaphyseal fractures comparing treatment with reamed and unreamed intramedullary nails. Our results show that reamed nailing is associated with a significantly lower time to union and a reduced requirement for a further operation. Unreamed nailing should not be used in the treatment of the common Tscherne C1 tibial fracture.

J Bone Joint Surg [Br] 1996;78-B:580-3.

Received 5 January 1996; Accepted 6 February 1996

There has been considerable debate about the merits of reaming in the treatment of tibial diaphyseal fractures. Proponents of unreamed nailing have suggested that intramedullary reaming is detrimental to the endosteal circulation and is therefore associated with a higher rate of nonunion and infection (Haas et al 1993; Renner et al 1993; Gregory and Sanders 1995). Studies on the effect of reaming on the osseous circulation have been contradictory. Klein et al (1990) showed that reamed tibial nailing reduced the cortical blood flow by about $70 \%$ compared with $30 \%$ in unreamed nailing. Schemitsch et al (1994) found that cortical vascularity took six weeks to return to normal in tibiae treated by an unreamed nail compared with 12 weeks if a reamed nail was used. A recent study by Reichert, McCarthy and Hughes (1995), however, has shown that reaming of the intact ovine tibia is associated with a six-fold increase in periosteal blood flow. Despite the importance of these studies it is likely that only prospective, randomised clinical trials will resolve the debate concerning the effects of reaming.

C. M. Court-Brown, MD, FRCS Ed(Orth), Consultant Orthopaedic Surgeon

E. Will, Grad Dip Phys, MCSP, Research Physiotherapist

J. Christie, FRCS, Consultant Orthopaedic Surgeon

M. M. McQueen, MD, FRCS Ed(Orth), Consultant Orthopaedic Surgeon Orthopaedic Trauma Unit, Royal Infirmary of Edinburgh NHS Trust, Lauriston Place, Edinburgh EH9 3YW, UK.

Correspondence should be sent to Mr C. M. Court-Brown.

(C)1996 British Editorial Society of Bone and Joint Surgery 0301-620X/96/41222\$2.00
In the clinical situation, interest has focused mainly on the treatment of severe open fractures. Advocates of unreamed nailing suggest that reaming will damage the intramedullary circulation and further compromise a bone which is already severely injured. There is little evidence to support this belief. Views have centred on the type of nail with little consideration of the importance of surgery to the soft tissues in the management of these difficult fractures. The only prospective randomised study comparing reamed and unreamed nailing in the management of open tibial fractures showed no difference between the two methods of treatment (Keating et al 1994). There has been no previous randomised study of closed fractures.

In most studies of the use of intramedullary nailing in closed tibial fractures the classification of the fractures has been inadequate. The Tscherne classification (Oestern and Tscherne 1984) separates closed tibial fractures into four types based on the degree of soft-tissue injury and the radiological appearance. A previous study (Court-Brown, Christie and McQueen 1990) indicated that the prognosis was different for the four Tscherne groups showing an increasing time to union between $\mathrm{C} 0$ and $\mathrm{C} 3$ fractures. This suggests that information from studies which combine all closed tibial diaphyseal fractures is of limited value and that any investigation should consider only one type of fracture. In a recent study of the epidemiology of tibial diaphyseal fractures we showed that $76.5 \%$ were closed and that $53.6 \%$ of these were Tscherne C1 (Court-Brown and McBirnie (1995). We therefore felt it appropriate to undertake a prospective, randomised study of reamed and unreamed nailing in these fractures.

\section{PATIENTS AND METHODS}

Between January 1993 and January 1994 we performed a prospective, randomised trial on 50 patients with unilateral Tscherne C1 tibial diaphyseal fractures comparing the reamed Grosse-Kempf tibial nail with the unreamed AO UTN nail. The patients were randomly allocated equally to the two groups by the use of prefilled envelopes. All the fractures were treated by primary intramedullary nailing using a standardised technique. The Grosse-Kempf nails were inserted using the technique of Court-Brown et al (1991) with nails of at least $11 \mathrm{~mm}$ in diameter. The AO 
nails were inserted according to the manufacturer's instructions and were 8 or $9 \mathrm{~mm}$ in diameter. All were statically locked but not all possible cross-screw holes were used. All patients were given $1.5 \mathrm{~g}$ of prophylactic cefuroxime at induction of anaesthesia and a further $750 \mathrm{mg}$ of cefuroxime six and 12 hours later. Compartment pressure monitoring as described by McQueen, Christie and Court-Brown (1990) was used in all patients.

The mean age of the reamed group was 35 years and of the unreamed group 36.1 years. In the reamed group $78 \%$ were male compared with $68 \%$ in the unreamed group. Each group contained one multiply-injured patient and five who had been injured in road-traffic accidents. The remaining patients had low-velocity injuries. Twenty-three of the reamed group and 20 of the unreamed group had AO typeA fractures (Müller et al 1990).

All patients had a similar postoperative regime. Physiotherapy of the knee, ankle and subtalar joints was begun on the day after operation and early weight-bearing was encouraged. No cast or brace was applied and the patients were discharged as soon as their condition allowed. All were followed up for one year in a research clinic, and a detailed assessment of outcome was undertaken by a research physiotherapist including time to union, the incidence of malunion and infection and the need for further surgery. The frequency of nail-related anterior knee pain and equipment failure was noted. Mobility of the knee, ankle and subtalar joints was assessed at three months, six months and one year, as were a number of basic activities, including the ability to get into awkward positions, kneeling, stooping or crawling, prolonged walking, walking upstairs, walking over difficult ground, jumping, and climbing ladders. The time to return to work was also noted.

Union of the fracture was assessed by standard radiological and clinical criteria (Court-Brown et al 1990). Malunion was defined as more than $5^{\circ}$ of angular or rotatory malalignment or more than $1 \mathrm{~cm}$ of leg-length discrepancy. The need for further surgery was assessed according to the criteria established by Court-Brown et al (1990, 1995). We performed exchange nailing if there was radiological evidence of atrophic union at 12 to 14 weeks after fracture, or when there was persistent evidence of hypertrophic nonunion at a later date.

Statistical analysis used the Mann-Whitney test to assess the difference in time to union and Fisher's exact test for the difference in the requirement for secondary operation.

\section{RESULTS}

The mean time to union for patients treated with the reamed intramedullary nail was 15.4 weeks (11 to 25 ) which was significantly less $(\mathrm{p}<0.01)$ than the 22.8 weeks $(12$ to 36$)$ for the unreamed group. The reason is that five $(20 \%)$ of the unreamed group required exchange nailing to facilitate union whereas all the reamed group united without a further operation. The $\mathrm{p}$ value for the difference in the

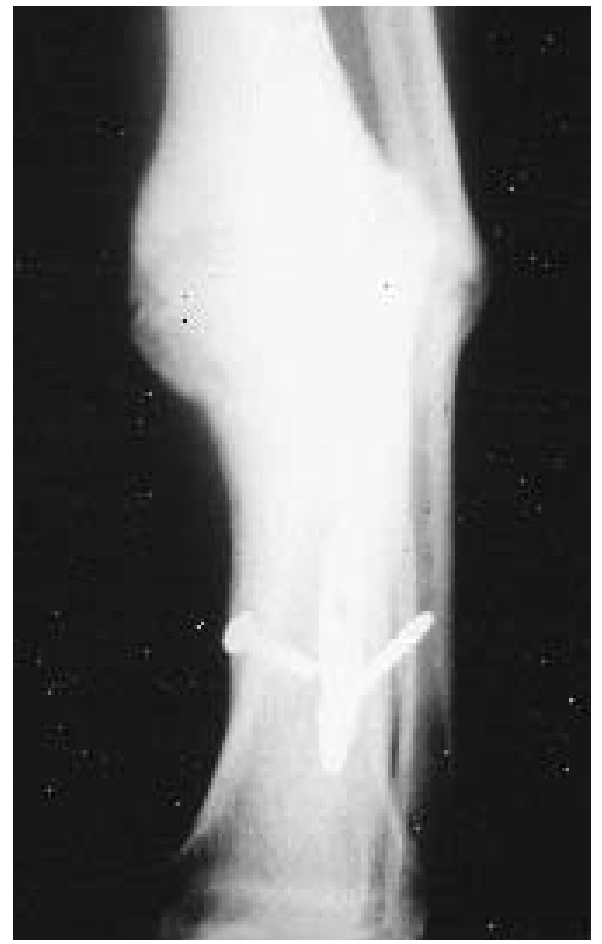

Fig. 1

Hypertrophic nonunion associated with a broken nail and a broken cross-screw. Union occurred after reamed nailing but the distal part of the unreamed nail had to be removed through a window in the tibia. The removal of solid fragments of nail is often difficult.

requirement for further surgery was exactly 0.05 . This does not quite reach conventional significance but is strongly in favour of the reamed nail. All five fractures united after exchange nailing with a reamed Grosse-Kempf nail, the mean time to union being 37.1 weeks after the initial nailing. No patient required open bone grafting.

There were no malunions in the reamed group but there were four cases $(16 \%)$ in the unreamed group. This was related to the high incidence of implant failure in this group in which $13(52 \%)$ of the patients had breakage of screws and one (4\%) had a broken nail (Fig. 1). No nails broke in the reamed group and only one patient had a broken crossscrew. A compartment syndrome occurred in two (8\%) of the reamed group and in three $(12 \%)$ of the unreamed group. There were no cases of superficial or deep infection.

Table I shows the mobility of the knee, ankle and subtalar joints at six months and one year after nailing, expressed as a percentage of the normal side. There is no significant difference between the two nails but there is impairment of hindfoot mobility in both groups at six months compared with the final result. Table II shows the time to return to the various basic activities. There are only minor differences between the two groups. There was no significant difference in the time of return to work with an average of 10.9 weeks for the reamed group and 9.3 weeks 
Table I. Joint movement at 26 and 52 weeks after fracture expressed as a percentage of the normal joint movement

\begin{tabular}{clllcc}
\hline & $\begin{array}{l}\text { Knee } \\
\text { flexion }\end{array}$ & $\begin{array}{l}\text { Ankle } \\
\text { dorsiflexion }\end{array}$ & $\begin{array}{l}\text { Ankle } \\
\text { plantar flexion }\end{array}$ & Eversion & Inversion \\
\hline 26 weeks & & & & & \\
GK nail & 98.1 & 73.1 & 86.7 & 83.0 & 78.0 \\
AO nail & 97.6 & 80.4 & 81.6 & 87.8 & 84.8 \\
52 weeks & & & & & \\
GK nail & 96.0 & 76.7 & 102.6 & 92.1 & 103.3 \\
AO nail & 98.3 & 83.0 & 86.9 & 100.8 & 92.1 \\
\hline
\end{tabular}

for the unreamed. The incidence of knee pain was also virtually identical with $15(60 \%)$ patients having nailrelated anterior knee pain in the reamed group compared with $14(56 \%)$ in the unreamed.

\section{DISCUSSION}

Our study indicates that the use of the unreamed nail in the management of the common Tscherne $\mathrm{C} 1$ tibial diaphyseal fracture gives a significantly prolonged time to union, a notable incidence of nonunion with the need for a further operation and a high rate of failure of the implants compared with the reamed nail. The difference in the requirement for exchange nailing was considerable although the $\mathrm{p}$ value of 0.05 just fails to reach significance because of the small numbers. We have previously described an incidence of $3.1 \%$ for exchange nailing in 261 such fractures treated by a reamed nail (Court-Brown et al 1995) and now avoid using an unreamed nail because of the potential complications.

The fractures which developed nonunion showed no unusual features. They were all AO type-A fractures and were not obviously distracted at the time of operation. They
Table II. The time taken in weeks to return to various basic activities

\begin{tabular}{llc}
\hline & GK nail & AO nail \\
\hline Awkward positions & 17.2 & 11.8 \\
Kneeling & 14.5 & 9.1 \\
Stooping/crawling & 13.0 & 10.7 \\
Long walks & 10.9 & 9.1 \\
Stairs & 11.4 & 10.6 \\
Difficult ground & 16.4 & 10.9 \\
Jumping & 10.7 & 13.6 \\
Climbing & 5.1 & 14.6 \\
\hline
\end{tabular}

were caused by low-velocity injuries with three resulting from a simple fall and two from sports injuries. One of these five patients developed a compartment syndrome and required a fasciotomy.

Three of the malunions were related to screw breakage and one was associated with breakage of both screw and nail (Fig. 1). In general, breakage of the cross-screws did not produce any significant sequelae although in one patient there was penetration of the ankle (Fig. 2). The frequency
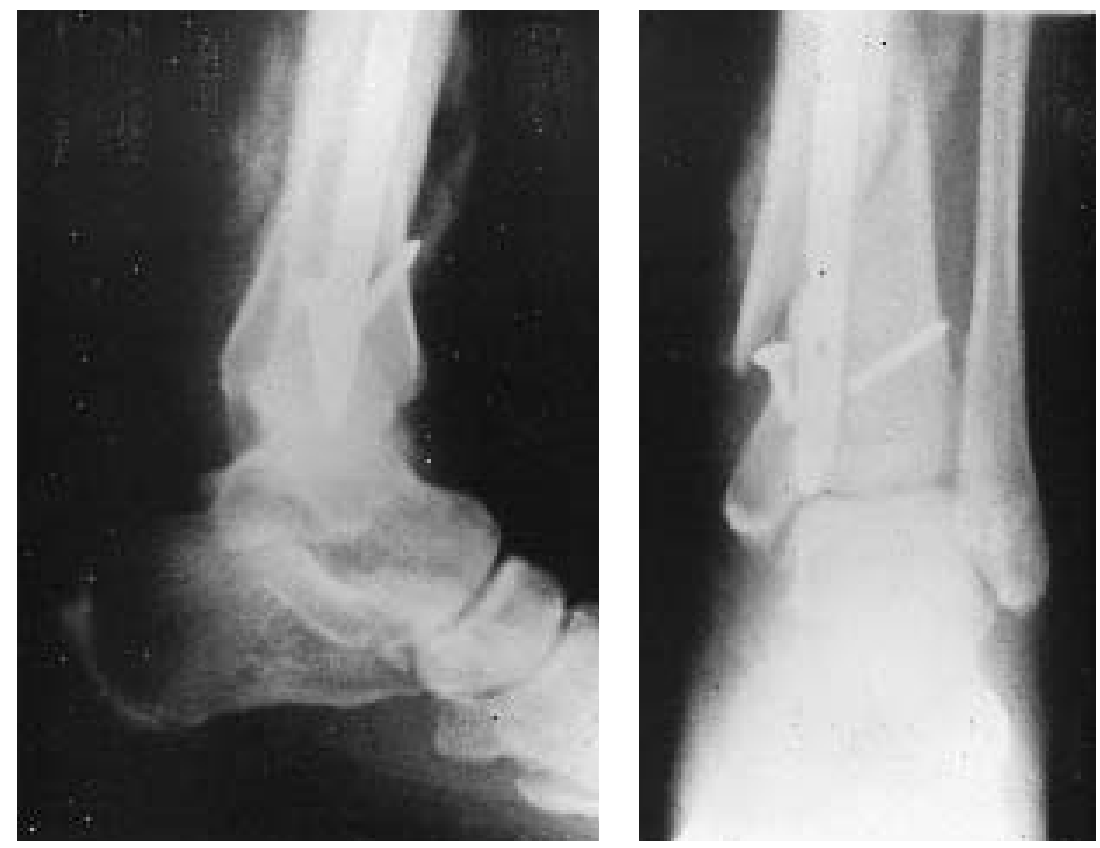

Fig. 2

Broken cross-screws rarely present a problem but penetration of the ankle occurred in this patient after breakage of a cross-screw. 
of screw breakage was such that towards the end of the trial we left $1 \mathrm{~cm}$ of screw thread protruding from the distal cortex to facilitate removal of the fragment if required. The relatively high incidence of screw breakage may be related to the fact that patients were allowed to bear weight as soon as they could; this is not recommended by the manufacturer. We have, however, followed this practice since 1986 and any change would have been a retrograde step. It is possible that screw failure in unreamed nails is independent of early weight-bearing; other authors have reported similar problems in patients who were not allowed early weight-bearing (Haas et al 1993; Renner et al 1993; Gregory and Sanders 1995).

We found that the AO unreamed nail was well engineered and easy to use and we did not encounter problems with fracture distraction or with inserting the nail into the unreamed distal tibial metaphysis. The main complication in our study was anterior knee pain, but there was no difference in the incidence between the groups despite the different shape of the proximal end of the two nails.

Recent papers dealing with exchange nailing have shown that reaming is very effective in promoting union (CourtBrown et al 1995; Templeman et al 1995). We believe that our results confirm the usefulness of intramedullary reaming and do not support the use of unreamed nails in the treatment of Tscherne $\mathrm{C} 1$ closed tibial fractures.

Although none of the authors have received or will receive benefits for personal or professional use from a commercial party related directly or indirectly to the subject of this article, benefits have been or will be received but are directed solely to a research fund, foundation, educational institution, or other non-profit institution with which one or more of the authors is associated.

\section{REFERENCES}

Court-Brown CM, Christie J, McQueen MM. Closed intramedullary tibial nailing: its use in closed and type I open fractures. J Bone Joint Surg [Br] 1990;72-B:605-11.

Court-Brown CM, McQueen MM, Quaba AA, Christie J. Locked intramedullary nailing of open tibial fractures. J Bone Joint Surg [Br] 1991;73-B:959-64.

Court-Brown CM, McBirnie J. The epidemiology of tibial fractures. J Bone Joint Surg [Br] 1995;77-B:417-21.

Court-Brown CM, Keating JF, Christie J, McQueen MM. Exchange intramedullary nailing: its use in aseptic nonunion. J Bone Joint Surg [Br] 1995;77-B:407-11.

Gregory P, Sanders R. The treatment of closed, unstable tibial fractures with unreamed interlocking nails. Clin Orthop 1995;315:48-55.

Haas N, Krettek C, Schandelmaier P, Frigg R, Tscherne H. A new solid unreamed tibial nail for shaft fractures with severe soft tissue injury. Injury 1993;24:49-54.

Keating JF, O'Brien P, Blachut P, Meek RW, Broekhuyse H. Interlocking intramedullary nailing of open fractures of the tibia: a prospective randomised comparison of reamed and unreamed nails. J Bone Joint Surg [Br] 1995;77-B Suppl I:73.

Klein MP, Rahn BA, Frigg R, Kessler S, Perren SM. Reaming versus non-reaming in medullary nailing: interference with cortical circulation of the canine tibia. Arch Orthop Trauma Surg 1990;109:314-6.
McQueen MM, Christie J, Court-Brown CM. Compartment pressures after intramedullary nailing of the tibia. J Bone Joint Surg $[\mathrm{Br}]$ 1990;72-B:395-7.

Müller ME, Nazarian S, Koch $\mathbf{P}$, Schatzker J. The comprehensive classification of fractures of long bones. Berlin, etc: Springer-Verlag, 1990.

Oestern H-J, Tscherne H. Pathophysiology and classification of soft tissue injuries associated with fractures. In: Tscherne $\mathrm{H}$, Gotzen L, eds. Fractures with soft tissue injuries. Berlin, etc: Springer-Verlag, 1984:1-8.

Reichert ILH, McCarthy ID, Hughes SPF. The acute vascular response to intramedullary nailing: microsphere estimation of blood flow in the intact ovine tibia. J Bone Joint Surg $[\mathrm{Br}]$ 1995; 77-B:490-3.

Renner N, Regazzoni P, Babst R, Rosso R. Initial experiences with the unreamed tibial nail. Helv Chir Acta 1993;59:665-8.

Schemitsch EH, Kowalski MJ, Swiontkowski MF, Senft D. Cortical bone blood flow in reamed and unreamed locked intramedullary nailing: a fractured tibia model in sheep. $J$ Orthop Trauma 1994;8:373-82.

Templeman D, Thomas M, Varecka T, Kyle R. Exchange reamed intramedullary nailing for delayed union and nonunion of the tibia. Clin Orthop 1995;315:169-75. 